\title{
Determinants of Bancassurance Adoption in Emerging Economies: Qualitative Evidence from Uganda
}

\author{
Eva Mpaata*, Rachel Mindra, Denis Ignatius Oula \\ Department of Finance, Faculty of Commerce, Makerere University Business School, Uganda \\ empaata@mubs.ac.ug
}

\begin{abstract}
This study was conducted to establish the determinants of bancassurance adoption in emerging economies. The research adopted a qualitative approach based on interviews as a main form of data collection. The study pursued an inductive approach in order to generalize the results. In the analysis process, NVIVO software was used to analyze in detail the different qualitative responses obtained from the data collection phase. The research concentrated primarily on urban Kampala, which is endowed with the majority of commercial banks. This study provides a good insight into the factors (both internal and external) banks consider essential while providing the bancassurance service. As a result other prospect banks can be guided by these factors in their need to provide the bancassurance service. The research explores the supply side of the determinants banks focus on while providing bancassurance. This is new as the majority of studies take a look at the banks' demand-side perspective. In addition, the challenges faced by banks in offering bancassurance while providing alternatives to prospective banks are being included in the adaptation of bancassurance. The research is purely qualitative as opposed to most previous findings, which are either solely quantitative or partly quantitative and partly qualitative with respect to the determinants of the adoption of bancassurance. Specifically, the focus on bancassurance research in Uganda is also new and original, since bancassurance is new in Uganda.
\end{abstract}

Keywords: Bancassurance, adoption, emerging economies, Uganda, supply-side.

\section{Introduction and Motivation of Study}

Given the unprecedented era of change in the finance sector characterized by new technologies, new customer expectations, new regulations and new competitive pressures that are rapidly disrupting the traditional, financial business model banks and insurance companies have left no choice but to consolidate, hence bancassurance models. Banking and insurance are two important integrated financial services that affect not only individuals and companies, but also have a direct effect on the economic health of emerging economies (Al-Khalifah, 2018; Claessens, 2014). Many banks in these economies have not opted to fully provide bancassurance services and this is why it was necessary to consider the determinants of the bancassurance adoption and to decide if these determinants are in position to encourage other banks to provide the service. Integrated Financial Service Provision (IFSP) is beneficial to economies and firms as it improves the efficiency of the financial sector, broadens access to financial services, and reduces specific financial sector and overall economic volatility (Claessens, 2014). As bancassurance is a new innovation in the financial services sector in Uganda, an in-depth study of the determinants of its adoption is essential to the financial sector's innovation process in order to achieve a more sustainable financial system. The rise and penetration of Bancassurance.

Kayonde (2017) has been one of the major technology trends in the financial services sector in the last few decades. This work is also useful in Uganda, as Uganda's financial sector was the latest economy to adopt the business model for bancassurance (IRA, 2016). In Uganda, banking and insurance have undergone a great deal of change and growth as a result of innovative and supportive regulatory system changes see Financial Institutions Act, (2016) as amended that allow for technical innovations and synergic operations among sectors. The bancassurance industry is at an all-time high in terms of competition in Uganda and providers are challenged to attract new customers while retaining existing ones (Fan, Lai, \& Lu, 2013). The identification of key determinants of the bancassurance business model embraced by insurance firms and commercial banks is therefore not only a vital competitive differentiator, but a requirement. Bancassurance is an evolving model for the sale / distribution of insurance products through the banking network, with the goal of growing market share, insurance penetration and thereby growing financial inclusion (Nyakomitta, 2017). Using the diffusion of innovation theory, the resource-based view theory and the unified theory of technology of acceptance and use, the study looked at factors that influence the adoption of bancassurance by commercial banks in Uganda. 
Context of Bancassurance in Uganda: Until the launch of Bancassurance, Uganda's insurance sector had risen to just 0.85 per cent. Nevertheless, with the introduction of Bancassurance, the redemption of Uganda's insurance sector grew to 18\%. After October 2017, 17 commercial banks have been approved as insurance agents by the Insurance Regulatory Authority. More partnerships continue to form between insurance firms and the bank. In 2018, licensed banks only collected US\$ 5.2 million (Ugx shs.19 billion) given the presence of a one-year bancassurance scheme. In this case, Stanbic Bank has a majority share of $50.22 \%$ of the premium booked in 2018. Barclays Bank came in second with 26.09\%, DFCU Bank with 7.57\%, Standard Chartered Bank with 5.29\% and Diamond Trust Bank with 3.14\%. Housing Finance Bank held a share of 2.14\%, Orient Bank (2.21\%), Bank of Africa (1.66\%), NC Bank (0.61\%), Exim Bank (0.35\%), Finance Trust (0.18\%), Kenya Commercial Bank (0.16\%), and the Unit (Bank of Uganda., 2018). The 2016 Financial Institutions Amendment Act called for the implementation of bancassurance in Uganda. The Bank of Uganda was responsible for drawing up regulations to promote the smooth operation of the law, which was further approved by the Ministry of Finance, enabling commercial banks to offer bancassurance thereby complementing their existing product bouquets (Financial Institutions Act, 2016).

Statement of the Problem: Bancassurance incentives are perceived to be far reaching for commercial banks, insurance firms and customers which eventually also impacts on the economy in terms of contribution to GDP (Bank of Uganda, 2017). The provision of integrated financial services has been found to strengthen customer relationships, offering additional services at reduced cost, building better customer loyalty and retention among others (Claessens, 2003; Loechel, Brost, \& Li, 2009). All these benefits are expected to be derived from the provision of bancassurance by the commercial banks if they get to offer insurance products alongside their traditional banking products. With the deregulation of insurance services in Uganda to allow commercial banks offer insurance products, many if not all, commercial banks were expected to embrace the bancassurance services to be able to enjoy the above benefits. This has however not been the case and according to IRA, (2018) report, the adoption rate has been termed as below par. In 2017 only two commercial banks out of twenty five were able to secure license to offer bank assurance and by December 2018, Eight (8) commercial banks had secured the license to offer the insurance services (IRA, 2018). What explains the slow adoption has not been established and research on bancassurance adoption in Uganda is still wanting. The majority of studies have been conducted in Kenya, Kombo (2019); (Mwangi, 2010) in addition to that, most of the empirical work on bancassurance focused on the benefits of bancassurance neglecting the determinants of its adoption (Arora \& ain, 2013; Claessens, 2003; Kombo, 2019).

\section{Methodology}

The Philosophical Perspective: The study adopts a subjectivism philosophy which is premised on the principle that knowledge is based on personal interpretation and meanings individuals attach to a given phenomenon (Cresswell, 2011). This was considered appropriate given that the study sought to determine the factors influencing bancassurance adoption by inquiring about individual perception and experiences. Accordingly, this study sought to fill the gap in literature on the factors determining the adoption of bancassurance in emerging economies using Uganda as a case study. According to Ritchie, Lewis, Nicholls, and Ormston (2013), subjectivism as a research philosophy in social science posits that results depend on personal perceptions and personality of the activities in a social phenomenon.

Research Design: The study adopted a qualitative and cross sectional research design which involved collecting data at a particular point in time from the respondents using interviewing data collection method. The Interview data collection technique was used to gain an in-depth understanding into the adoption of bancassurance given that it is still a new innovation (Cresswell, 2011). A semi-structured interview guide was used to generate the data necessary for the study purpose. Interviews have long been used in soliciting responses from respondents in regards to innovation/product adoption (Robertson \& Samy, 2015).The qualitative approach was considered appropriate for this study since it enables the researchers to solicit meanings and perception of individuals within the bank. The study also used an exploratory and narrative research approach which was deemed acceptable since it allows for an in-depth understanding of the phenomenon (Creswell, 2009; Yin, 2008). The research therefore used an inductive lens in the investigation focusing on generating new theory emerging from the data (Magelah \& Ntambirweki-Karugonjo, 2014). 
Study Population and Selection Method: The study population consisted of 24 licensed supervised commercial banks that were considered eligible to provide bancassurance services and informed by 15 respondents determined using the principle of saturation(Bank of Uganda, 2018). Saturation refers to the point at which additional data generated from the study no longer give any new information as the number of the respondents increases (Glaser, 2018). Data was collected from Head Offices located in Kampala, given that bancassurance services is currently available at Head Offices only. The respondents were selected purposively which was considered appropriate since the study sought to get response from specific persons with relevant information from the bank (Cresswell, 2011). The respondents included principal officers/coordinators, managers and credit officers. These individuals were specifically selected because of their ability to adequately inform the study on bancassurance adoption.

Data Management and Analysis: Data were transcribed using Microsoft Word and then captured in Nvivo software. To simplify the coding process, operational concepts were used with the encoded categories grouped under tree nodes. This involved grouping quotations from the transcripts that represent each subcategory. This process enables the researchers to use the participants' own words as much as possible to maximize accurate representation of their (participants) views as opposed to those of the researchers. After the coding process, cross case analysis was done. For each of the codes, the different personal and societal capabilities identified will be compared. Careful analysis of the coded record assisted in ensuring that the domains derived accurately reflected the participants' perspectives. Cross analysis helped to identify the different determinants of bancassurance while comparing them to each of the codes. Careful analysis of the coded record helped ensure that the generated domains accurately reflected the experience of the participants.

\section{Results, Discussion and Contribution of Study}

Demographics of the Respondents: The study collected data from 15 interviewees, 14 principal officers and 1 credit manager from registered commercial banks. As seen in the demographic characteristics Table I most of the key informants were aged between 36 and 45 years of age, males, married, had acquired at least a bachelor's degree and had over 5 years of experience in the insurance business.

Table 1: Characteristics of Respondents

\begin{tabular}{lllllll}
\hline Cases & Age & Gender & $\begin{array}{l}\text { Marital } \\
\text { Status }\end{array}$ & Level of Education & $\begin{array}{l}\text { Years in } \\
\text { Insurance } \\
\text { Business }\end{array}$ & $\begin{array}{l}\text { Position Held at } \\
\text { the } \\
\text { Bank }\end{array}$ \\
\hline 1 & $26-35$ & Male & Single & Bachelor's Degree & 7 & Principal officer \\
2 & $36-45$ & Male & Married & $\begin{array}{l}\text { Bachelor's Degree } \\
\text { Bachelor's Degree }\end{array}$ & 11 & Principal officer \\
3 & $46-55$ & Male & Married & Master's Degree & 9 & Principal officer \\
4 & $36-45$ & Male & Married & Credit manager \\
5 & $46-55$ & Female & Married & Bachelor's Degree & 11 & Principal officer \\
6 & $56-65$ & Male & Married & Bachelor's degree & 5 & Principal officer \\
7 & $56-65$ & Male & Married & Bachelor's Degree & 5 & Principal officer \\
8 & $36-45$ & Female & Married & Bachelor's Degree & 8 & Principal officer \\
9 & $36-45$ & Female & Married & Bachelor's Degree & 7 & Principal officer \\
10 & $36-45$ & Female & Married & Master's Degree & 11 & Principal officer \\
11 & $36-45$ & Male & Married & Bachelor's Degree & 12 & Principal officer \\
12 & $46-55$ & Male & Married & Bachelor's Degree & 6 & Principal officer \\
13 & $26-35$ & Male & Married & Bachelor's Degree & 8 & Principal officer \\
14 & $46-55$ & Male & Married & Bachelor's Degree & 5 & Principal officer \\
15 & $36-45$ & Male & Married & Master's Degree & 7 & Principal officer \\
\hline
\end{tabular}


Table 2: Transcript Analysis of Interview Responses

Questions Asked
Does your institution
provide bancassurance,
how would you describe
bancassurance?

What internal factors are bancassurance services in Uganda? likely to influence adoption of

\section{Sample Quotes from Respondents}

(Yes). Bancassurance is a platform for insurance companies to sell their products to both customers; possible banking customers and the general public. Bancassurance operates like a broker, an insurance broker in the bank .

Banks selling insurance policy to its existing customers and we currently sell insurance policies for five different insurance companies

It is easy for banks to create awareness to the customers who are already transacting with the bank.

The bank undertook the opportunity to be able to tap the noninterest revenue derived from selling insurance products . our culture requires that we be market leaders and therefore venturing into bancassurance is dictated by such culture .

What other external factors are likely to influence the adoption of bancassurance services in Uganda?

How has bancassurance influenced the banks performance
"All insurance companies cannot reach up to all the customers but banks have customers who frequently come to the bank dedicated counter for selling insurance products."

Customers trust in the bank and We have 69 branches and these branches should be selling insurance but due to knowledge gap, we are not yet able to roll out bancassurance country wide and bankers also have certain way they operate different from how insurance sector operate so we have to train them .

The kind of setup you have with the insurance as well as the support the insurance company is willing to offer

Religion may also influence the adoption of bancassurance given that the Muslim faith discourage earning interest on money . the customer belief in their bankers has contributed to the adoption of the product

...... The industry is young and growing firms are only allowed to adopt bancassurance when they meet the requirements of the regulatory bodies

Bancassurance gives us opportunity to earn noninterest revenue arising from commission on sales Improvement in the level of income arising from non-interest income
Emerging Themes

Distribution of insurance products through the bank.

Selling of insurance policies through banks to bank customers.

A channel through which insurance is sold through the bank.

Selling insurance through the bank

Readily Available market

Management perception about insurance

Becoming a one stop center

Corporate culture

Additional income

Well trained staff

Top management support

Company objective

Availability of resources

Investment policy

Insurance is a need

Dedicated counters

Regulatory requirements

Competition from brokers and agents

Knowledge gap

Customer trust in the bank

Market prospects

Relationship with the insurance company

Support from insurance firms

Perception about insurance products.

Innovativeness

Customer trusts in the bank.

Belief in insurance products.

Religion

Customers' trust in the bank. The industry growth prospect Regulatory requirements

Improve revenue level Increased noninterest revenue Improvement in income Competitive edge in insurance Increased product range offered 


\section{Questions Asked}

What are the limiting factors to adoption of bancassurance services in Uganda? Please elaborate.

How best can adoption of bancassurance services in Uganda be improved?

\section{Sample Quotes from Respondents}

May be some of them didn't want to invest because it requires some investments which include investing in people, and facilities but they are missing on commission income .

.........Perception of the potential clients who believe insurance is an expenses/luxury not a necessity. Limited insurance products which are not customized to the needs of the local persons .

The biggest challenge is what we call the market forces, these are things we can't control, first is acceptance of insurance is still low. So, people are not willing to put in a lot of money and the level of investment is a bit low.

Other banks offering bancassurance are not affecting our performance but the normal intermediaries that are offering kickbacks to get deals which we cannot. . Others are lack of information about insurance products and its benefits to other banks. Limited penetration of insurance products to the local population discourages other banks from adopting bancassurance . Lack of capacity to undertake bancassurance in that bancassurance may only be adopted by banks that had prepared themselves and developed capacity .

Understanding customer needs such that the product is tailored to the client; this may be achieved through conducting research on the needs of the customers to be able to categorize them according to their needs. Banks needs to go digital and understand its clients to be able to tailor making the products For insurance to succeed, they need to be supported by government

Payment of claims should also be improved by the insurance companies. If people get to realize that these claims are actually paid without hustle, it could market the insurance products to the masses .

\section{Emerging Themes}

by the bank.

Attracts new clients

Customer perceptions about insurance

Lack of customized insurance products.

Acceptance of insurance

products

Low level of investments

Insurance being a new sector.

Lack of government support.

Perception about insurance

Corrupts practices by other intermediaries

Low penetration of the insurance products

Lack of information about insurance products.

Capacity to undertake bancassurance

Perception of the potential customers

Market penetration

Lack of prioritization

Limited human resources

Perceived Lack of market

Understanding customers

Conducting more research

Digitization

Product customization for the

local population

Government support

Sensitization

The need for training

Staff training

Creating awareness.

Sensitization

Improve claim payment

Results: The study was conducted to determine the factors that influence bancassurance adoption by commercial banks in Uganda. Results in Table II indicate the responses generated from the interviewees and these captured both internal and external factors which are believed to influence bancassurance adoption. The internal factors that were identified included mainly; management perception about insurance, capacity in terms of human resources, additional income, becoming a one stop center, bank culture, well trained staff, a readily available market, earning non-interest income, customer retention, gaining new customers, top management support, supportive staff, company objective, availability of financial resources and investment policy. 
Corporate Culture: Respondents argued that for a bank to take up a new product, it must fall within its corporate objectives. They further indicated that the strength of the bank to beat competition lies in its ability to innovate and introduce new products for which bancassurance presented an opportunity. One of the respondents had this to say.

Noninterest Revenue: Respondents argued that bank took interest in adopting bancassurance because of the possibility to earn noninterest revenue as an additional source. A number of respondents indicated that it would not be wise for any bank not to take up bancassurance because they are indirectly selling insurance products embedded in loans and investment products which revenue was going to the brokers.

Product Diversification: Some respondents argued that introduction of bancassurance services broadens the product range for the bank and that creates a one stop entre for its clients. They further argued that introduction of bancassurance would go a long way to create customer loyalty and retention since all services can be obtained from the bank. From the excerpts some of the respondents had this to say; Respondent 5 "...our culture requires that we be market leaders and therefore venturing into bancassurance is dictated by such culture, we have well trained staff who are fit for purpose, we don't just pick anyone to handle bank services". Respondent 7: "The bank undertook the opportunity to be able to tap the noninterest revenue derived from selling insurance products." While according to respondent 6: "Besides noninterest income, Banks would want to be a one stop Centre for its customers, it's the way to go, that's why they are also going into agency banking, they are trying to be innovative."

Top Management Support: A number of respondents argued that adoption is mostly based on the perception held by top management. They indicated that it is very critical for management to take interest in an innovation if it is to ever succeed because they make the strategic decisions. Some argued that bancassurance was adopted because top management took interest in it and pledged their support by establishing separate unit to handle the products for instance from the excerpts.

Resource Availability: Some respondents argued that adoption is based on the bank's capacity in terms of both financial and human resources. They indicated that some banks may not be able to adopt bancassurance due to lack of financial capacity to inject in the new product line while other contended that human resources is equally an important factor that influences adoption. They further stated that insurance need a dedicated counter and group of staff assigned specifically to sell insurance policies but not juggling both banking and insurance products.

Readily Available Market: Many respondents indicated that banks took up bancassurance due to its readily available customers being served by the bank. They noted that most of their clients who sought insurance policies outside the bank can now be served within the bank. Other respondents indicated that all loan applicants are expected to pay for insurance and this constitute a huge market for the bank. For instance, from the excerpts the following were noted; Respondent 4 asserted that "......some banks do not look at insurance as a serious business opportunity to invest in...yet the only way to succeed in offering bancassurance is by having support from top management" Respondent 1 ".........the bank has a dedicated counter with designated officers trained to sell bancassurance to the clients. Respondent 6 "...............bancassurance may only be adopted by banks that had prepared themselves and developed capacity . ".......we have 69 branches and these branches should be selling insurance but due to resource gap, we are not yet able to roll out bancassurance country wide and bankers also have certain way they operate different from how insurance sector operate so we have to train them....." Respondent 1; ".....It is easy for banks to create awareness to the customers who are already transacting with them while Respondent $\mathbf{1 1}$ argued that; ".....Banks are expected to sell to their existing clientele base".

Regulatory Requirement: The respondents indicated that a bank can only be allowed to provide bancassurance services when it meets the requirements set by regulatory bodies. They indicated that before taking up bancassurance services, each bank must be licensed by the insurance regulatory authority.

Competition: Other respondents argued that adoption of bancassurance is influenced by the level of competition in the industry. Most of the respondents indicated that the insurance brokers were the major 
competitors for bancassurance since they have been in the business for selling insurance products for a long time.

Figure 1: Internal Factors that Influence Adoption of Bancassurance

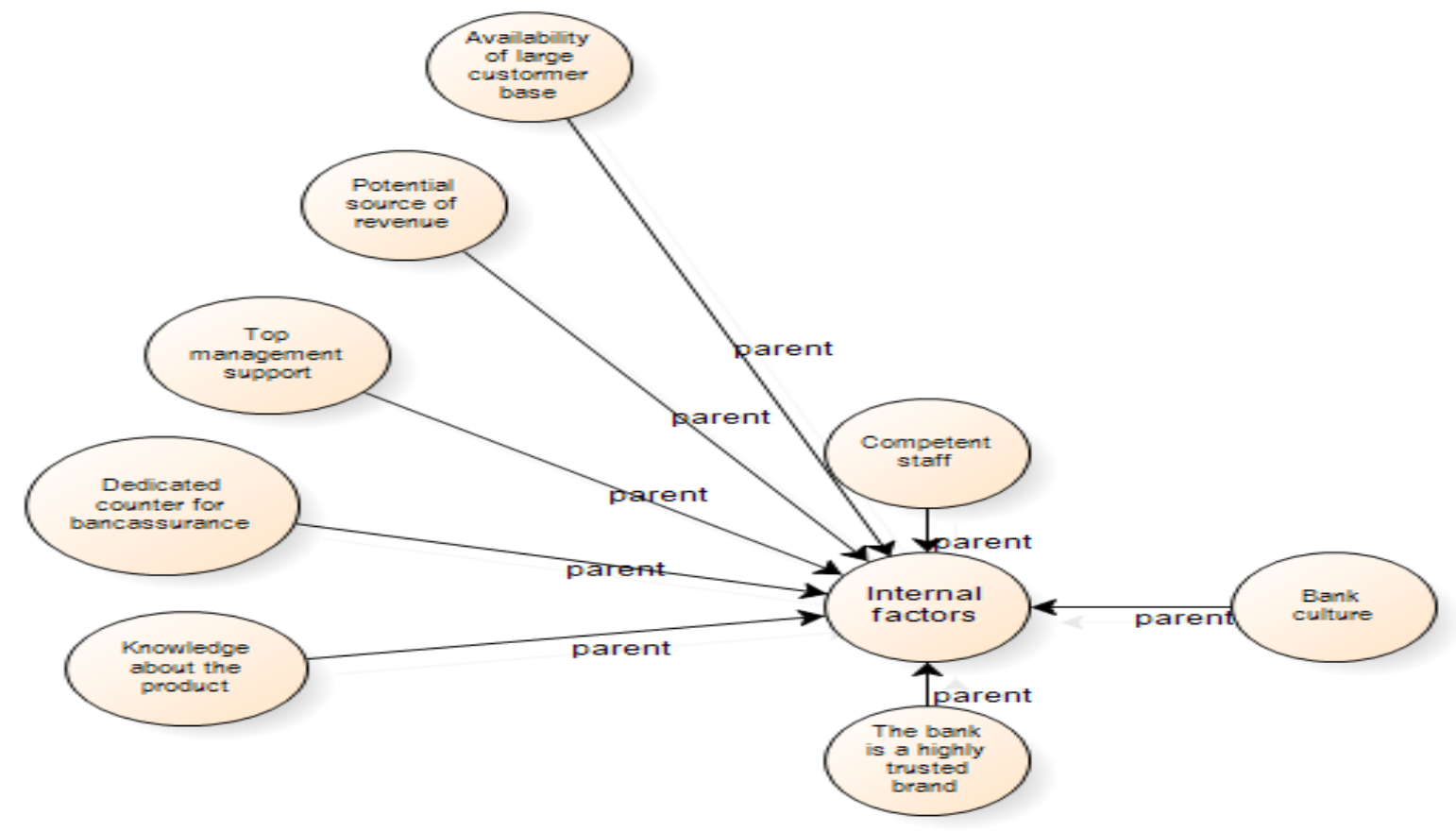

Respondents were also asked about the external factors that were likely to influence the adoption of bancassurance services in Uganda and from Table II, many respondents argued that the following factors were pertinent; Regulations, competition, market prospects and growth, external trust by customers and support offered by insurance companies among others.

Customers Trust in the Bank: The respondents also indicated that the banks are taking up bancassurance because of the trust that customers have in them. They indicated that most customers do not trust insurance companies and were not willing to take up insurance policies but because this time the banks will be offering the services, they have begun asking for the products.

Market Prospects and Industry Growth: Some respondents argued that the prospect of insurance industry growth was one of the reasons the bank took up bancassurance services. They further stated that many bank clients are now taking up different insurance policies such as education, property and even investment policies among others which the bank believes could be offered from within their premises. Others indicated that insurance is becoming a necessity and with time many people will be interested in taking up the different policies which will be beneficial for the banks that are already offering. For instance one of the excerpts was captured as indicated below; Respondent 10:" ...... the insurance industry is young and growing with good market prospects while respondent 1; "....... Insurance is a necessity and treated as a need for everyone by the bank. Respondent 12:"..... banks are only allowed to adopt bancassurance when they meet the requirements of the regulatory bodies.

Respondent 11: “........the banks have been aware of the competition fronted by the insurance agents and brokers...." Respondent 11: ".................when the banks were allowed to offer bancassurance, the clients began trusting the banks more than the insurance agents............. the customer belief in their bankers has contributed to the adoption of the product.". They also emphasized that from an organizational point of view, innovations require an effort to recognize the selection and presentation of the finest technologies while enhancing the way of generating, obtaining, handling and transmitting knowledge from customers to 
companies and vice versa. Similarly, Ahmadinia, Karim, and Ofori (2015) assert that the use of technology becomes smart by connecting retails and clients with mutual goals of achieving better customer dynamics and customer experience.

Figure 2: External Factors that Influence Bancassurance

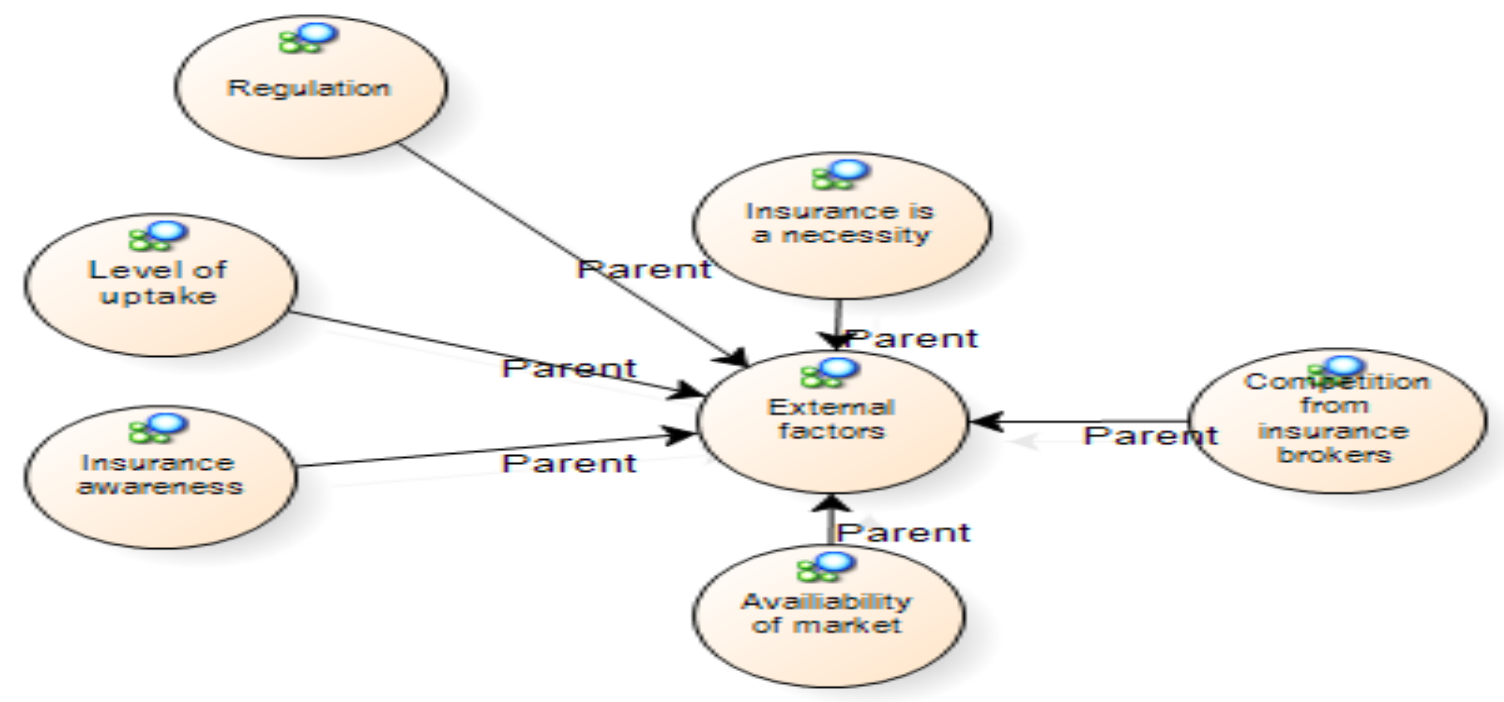

Previous studies on the factors influencing bancassurance adoption were supported by the above finding. Omondi (2013) analyzed the determinants of adoption of bancassurance by commercial banks in Kenya. He found that bancassurance was influenced by the need for diversification and new revenue streams. Pantano and Timmermans (2014) studied the implementation of smart technologies in retail in both selling activities and business. Furthermore, Lovelin and Sreedevi (2014) studied bancassurance in India and found that customer loyalty influences the purchase of insurance products. This is reflected on the perception that the customers have trust in the banking sector compared to the insurance brokers. Additionally, Mwangi (2010) argued that in order to improve bancassurance in Banks, customer access, a larger market share and government support were crucial factors.

Challenges of Bancassurance Adoption in Uganda: Despite the advantages associated with bancassurance in Uganda, the respondents argued that the service still faces some challenges which included among others; Customer perceptions about insurance, Lack of customized insurance products, Acceptance of insurance products, Low level of investments, lack of awareness, Lack of government support, Corrupt practices by other intermediaries, and These responses are well elaborated by the data extracted from the interview responses as indicated in Table II. Respondent 2 "........... acceptance of insurance is still low......people are not willing to put in a lot of money and the level of investment is a bit low Respondent 8: "....................the one mismatch we have is the government, government does not believe in insurance" Respondent 14: ".....the perception is a different story but if the government who is the biggest employer does not believe in insurance the penetration will always remain like that." Respondent 3: noted ".........lack of information about insurance products and its benefits to other banks also, lack of capacity to undertake bancassurance in that bancassurance may only be adopted by banks that had prepared themselves and developed capacity." According to Respondent 8 ".......People are biased about insurance products, it's very hard for someone to be told about insurance and get excited about it" Respondent 3: "..............bancassurance is not on the employee KPI and therefore most staff may not give it priority" Respondent 5 "......people do not see the need to insure and therefore market is perceived to be limited."

Strategies to Improve Bancassurance Adoption in Uganda: The study also sought to find out the best ways commercial banks can improve adoption and the respondents indicated the following strategies; top management support, stakeholder involvement, product customization, quick payments of claims, vigorous 
marketing, digitization of the system for easy accessibility and building capacity among others. This finding concurs with Bergendahl (1995) who noted that in order to improve bancassurance adoption, the banks must understand customer needs. On the importance of regulation in banking, researchers (Arthur \& Iris, 2003; Guttentag \& Lindsay, 1968) agree that a regulated banking and insurance sector reduces transaction costs. Indeed they point out that regulating the bancassurance business influences liquidity and performance and recommend that banks and insurance companies take advantage of efficiencies that come with embracing a regulated bancassurance business since this increases the trust customers may have with the service provider (bank).

\section{Figure 3: How to Improve Bancassurance Adoption in Uganda}

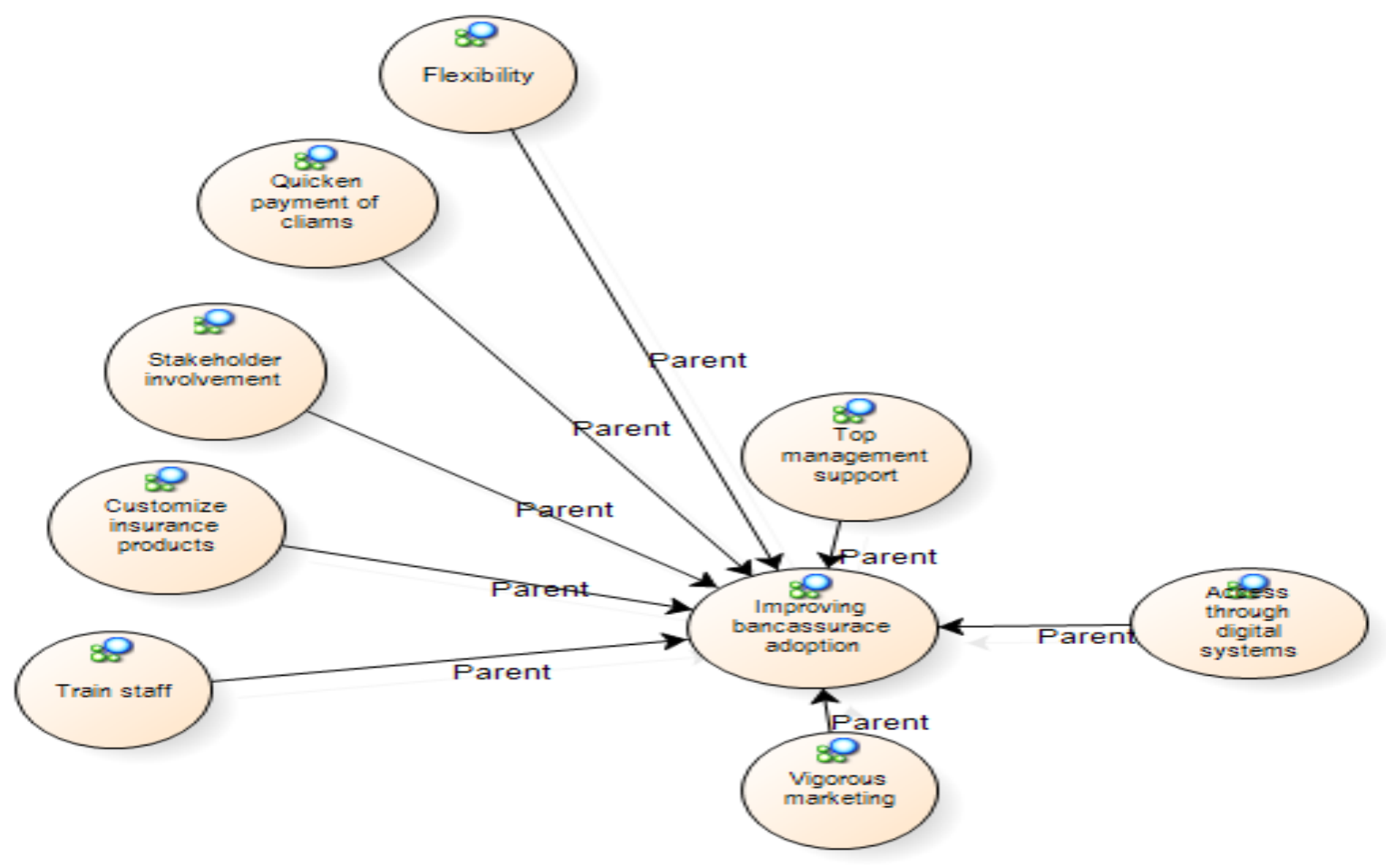

\section{Conclusion and Recommendations}

In Uganda, bancassurance is intended to drive the penetration of insurance service in the economy; providing key avenues or distribution of insurance products. Given the importance of bancassurance established in the study findings, the following conclusions are drawn. The key drivers of bancassurance adoption by commercial banks in Uganda include but not limited to; top management support, internal controls, the bank's investment policy, bank culture and already available insurance market have a strong impact on the rapid adoption of bancassurance by banks in Uganda. These undertakings enforce regulation and improve the bank culture as far as provision of bancassurance products is concern. They also improve on the relationship with the insurance companies. The external factors like; customer trust in a commercial bank, competition from brokers and agents, relationships between commercial banks and insurance companies, the influence of religion on customers insurance uptake as well as regulatory requirement are the main external factors driving the adoption of bancassurance services in Uganda. The study also found that there are a number of challenges surrounding bancassurance ranging from customer's biased perception about insurance, lack of awareness and lack of customized insurance products for the local market. These could be overcome through extensive outreach, government support, improved level of investments, insurance literacy will improve bancassurance uptake among commercial banks in Uganda. 


\section{Recommendations}

The study recommends that commercial banks in Uganda should put into consideration both the internal and external factors that impact on bancassurance adoption thereby attracting a bigger clientele and subsequently affecting their financial performance. This will increase their non-interest income as a result of bigger commissions in addition to the provision of a competitive platform given the wide range of products offered. Secondly, we recommend that commercial banks improve the working relationships with insurance companies. Firstly, commercial banks should seek to partner with insurance companies who have their goals aligned with the services that banks' services need. Secondly, both commercial banks and insurance companies must agree on the capacity in which they will be acting. For instance, they need to decide whether banks are operating as; pure distributors of insurance products; whether banks have strategic alliances with insurance companies; whether both banks and insurance companies are operating a joint venture; or whether the two are running a holding company.

Aligning the capacity in which banks and insurance companies operate is vital in the various decision-making processes. Such decisions include commissions and profit-sharing agreements. This will give commercial banks easier terms of business and improve their way on doing business. The study also recommends regular evaluation of bancassurance practices. For instance, getting a substantial customer base, ensuring good brand equity, making long term commitments, readiness to commit resources, (both technological solutions and marketing). Also, a regular review of the bancassurance products and services offered by the commercial banks to ensure that they are in line with the bancassurance regulations, 2017. To achieve this, the bancassurance regulators in the country like the Insurance Regulatory Authority must be committed to playing their supervisory role efficiently and effectively. There is need for government to enforce country wide financial literacy and insurance literacy trainings if adoption of bancassurance is to be achieved. This will help bank clients and prospective clients to appreciate the importance of insurance. It will also help them to make informed financial decisions.

\section{Theoretical and Practical Implications}

Theoretical Implications: Resource Based Value (RBV) illustrates the theory's practical value as a framework for strategic decision-making. Our findings clearly indicate that established competitive advantages based on resources and skills are apparent in financial institutions that provide bancassurance services. The portfolio of resources and how they are deployed, especially in the context of the business-to business marketing that is imperative in banks and insurance companies. Banks providing bancassurance ensure that resources are allocated strategically and effectively. This in turn gives financial institutions enormous flexibility which is a source of competitive advantage. Diffusion often involves an invention to be consistent with the adopters' (in this case banks) principles, interests, historical experience and current needs. With rapid technological advances, using the Innovation diffusion theory ensures changes in the way business is carried out and how the bank's daily routine activities are handled. In addition, since the banks have information about their customers in their databases that can be easily accessed using technology. Consequently, the innovation diffusion theory has been widely used to describe the implementation of innovations by financial institutions that could improve bancassurance adoption. Furthermore, the theory of Diffusion of Innovations helps to find reasons and explanations for spreading innovative ideas and technology. This research would also integrate the theory into the implementation of bancassurance provided by banks using three Rogers's theory models that include adopter styles, innovation-decision mechanisms, and innovation attributes.

Practical Implications: With the widening of the financial market with so many players entering the finance industry, it is expected that banks with insurance firms will produce new products, raise customer awareness of their goods and sell them at a reasonable price. New financial services entrants had no difficulty matching their products to the needs of the customers and offering them at a price that was acceptable to the customer. But the restructuring (bancassurance) has led to more concentration of payment and settlement flows by fewer parties within the financial sector. The integration of both the banking and insurance sectors leads to the emergence of very large financial institutions and non-insurance service providers who are specialized in providing a wide range of insurance services to third parties, thus increasing in-house transactions, no need 
to involve external exchange of payment messages and therefore tend to be cheaper to process. The areas for further research would include a comparative study on the performance assessment between bancassurance service providers and the third party insurance providers, a study to ascertain whether bancassurance inspires the uptake of insurance within Uganda and lastly whether bancassurance is a better delivery method for insurance services.

\section{References}

Adger, W. N., Brown, K., Fairbrass, J. \& Jordan, A. (2004). Governance For Sustainability: Towards A 'Thick' Understanding of Environmental Decision Making, 35(6), 1095-1110.

Ahmadinia, H., Karim, M. \& Ofori, E. (2015). Primary analysis of information distribution at walkbase Company: Developing an information strategy. The Journal of Industrial Distribution \& Business, 6(4), 5-16.

Al-Khalifah, A. (2018). The strategic stabilization of private banks and insurance company in the financial service sector. Journal of Humanities Insights, 2(04), 161-166.

American Association for the Advancement of Science. (2006). Project 2061 - Atlas of Science Literacy. Retrieved from http://www.project2061.org/publications/atlas/

Arora, A. \& ain, M. (2013). An analysis on contribution of bancassurance on financial performance of Bank of India. Journal of Economics and Sustainable Development, 4(6), 67-79.

Arthur, G. \& Iris, C. (2003). Assymetric Information, Financial Intermediation and the Monetary Transmission Mechanism. A critical Review. Working Paper, 3(19), 5-16.

Bank of Uganda. (2017). Promoting Financial Stability, 2016/17 Annual report. Retrieved from Kampala:

Bank of Uganda. (2018). Promoting Financial Stability, 2017/18 Annual report. Retrieved from Kampala:

Bergendahl, G. (1995). The profitability of bancassurance for European banks. International Journal of Bank Marketing, 13(1), 17-28.

Claessens, S. (2003). Benefits and costs on integrated financial services provision in developing countries. Brookings-Wharton papers on financial services, 1, 85-139.

Claessens, S. (2014). Benefits and costs on integrated financial services provision in developing countries. Brookings-Wharton papers on financial services, 1, 85-139.

Cresswell, K. M. (2011). Implementation and adoption of the first national electronic health record: a qualitative exploration of the perspectives of key stakeholders in selected English care settings drawing on sociotechnical principles. (PhD), The University of Edinburgh, Edinburgh.

Creswell, J. W. (2009). Research design: Qualitative, quantitative, and mixed methods approaches (Vol. 3rd ed.). CA:Sage: Thousand Oaks.

Department of Education. (2003). National Carriculum Statement Grades 10-12 (General): Mathematics. Retrieved from Government of South Africa:

Falk, J. \& Storksdieck, M. (2005). Using the contexual model of learning to understand visitor learning from a science centre exhibition. Science Education, 89(5), 744-778.

Fan, C. K., Lai, H. \& Lu, W. (2013). An Evaluation of Key Factors for Bancassurance Success. International Journal of Application or Innovation in Engineering \& Management (IJAIEM), 2(12), 190-197.

Glaser, S. (2018). The Death of Open Access in Lake Victoria. Retrieved from https://securefisheries.org/blog/death-open-access-lake-victoria

Guttentag, J. M. \& Lindsay, R. (1968). The Uniqueness of Commercial Banks. Journal of Political Economy, (71), 991-1014.

Heather, K., Laschinger, S., Finegan, J. E., Shamian, J. \& Wilk, P. (2004). A longitudinal analysis of the impact of workplace empowerment on work satisfaction. Journal of Organizational Behavior, 25, 527-545 527545.

HERFELD, C. (2012). The potentials and limitations of rational choice theory: an interview with Gary Becker. Erasmus Journal for Philosophy and Economics, 5(1), 73-86.

IRA. (2016). Annual Insurance Market Report. Retrieved from Kampala, Uganda:

IRA. (2018). Annual Insurance Market Report. Retrieved from Kampala:

Kayonde, L. (2017). Bancassurance Insights for the financial services Eye, Stanbic Bank Uganda - August.

Kombo, J. N. (2019). Determinants of the Adoption of Bancassurance Business Models by Commercial Banks in Kenya. Retrieved from. 
Loechel, H., Brost, H. \& Li, H. (2009). Benefits and Costs of Integrated Financial Services Providers (IFSP)State-of-the-Art in Research.

Lovelin, P. \& Sreedevi, V. (2014). Preference of Bancassurance. Journal of Business and Management, 16(1), 08-13.

MAAF. (2011). Department Of Fisheries Resources Annual Report 2010/2011. Retrieved from Kampala:

Magelah, P. \& Ntambirweki-Karugonjo, B. (2014). YOUTH UNEMPLOYMENT AND JOB CREATION IN UGANDA: Opportunities And Challenges. Retrieved from Kampala:

Mwangi, J. W. (2010). An assessment of the Determinants of growth of Bancassurance in Kenya.

Nyakomitta, G. 0. (2017). Challenges Faced By Commercial Banks in the Bancassurance Market in Kenya. Retrieved from School of Business, University of Nairobi:

Omondi, R. (2013). Determinants of adoption of bancassurance by commercial banks in Kenya.

Pantano, E. \& Timmermans, H. (2014). What is smart for retailing? Procedia Environmental Sciences, 22, 101107.

Ritchie, J., Lewis, J., Nicholls, C. M. \& Ormston, R. (2013). Qualitative research practice: A guide for social science students and researchers. sage.

Robertson, F. \& Samy, M. (2015). Factors affecting the diffusion of integrated reporting - a UK FTSE 100 perspective, Sustainability Accounting. Management and Policy Journal, 6(2), 190-223.

Stake, R. E. (2000). Case Studies In N. K. Denzin \& Y. S. Lincoln (Eds.), Handbook of Qualitative Research. Thousand Oaks, CA: Sage.

Yin, R. K. (2008). Case Study Research: Design and Methods. California: Sage Publication Inc. 